\title{
THE EFFECTS OF INTRAVENOUS INJECTION OF CONCENTRATED HUMAN SERUM ALBUMIN UPON BLOOD PLASMA, ASCITES AND RENAL FUNCTIONS IN THREE PATIENTS WITH CIRRHOSIS OF THE LIVER ${ }^{1}$
}

\author{
By ARTHUR J. PATEK, JR., HAROLD MANKIN, HENRY COLCHER, \\ ALICE LOWELL, AND DAVID P. EARLE, JR. \\ (From the Research Services, First and Third Medical Divisions, Goldwater Memorial Hospital, \\ and the Departments of Medicine, Columbia University and New York \\ University, New York City)
}

(Received for publication July 19, 1947)

The mechanism of ascites formation has been a subject of interest for many years and remains a challenge to the investigator. In previous reports $(1,2)$ on 61 patients with cirrhosis of the liver, it was pointed out that those with ascites have lower values for serum albumin than do those without ascites and that the tendency to diuresis (and the loss of ascites) was correlated with a rise of the serum albumin level. The "critical" point of diuresis was found to be about 3.1 grams per cent. However, the slowness of diuresis, frequently taking place over a period of several months, did not provide a sharp endpoint for establishing a critical level. Although other factors, such as an increased portal capillary pressure, were considered to be contributory, it seemed likely that the colloid osmotic pressure of the plasma was the chief determinant for the presence or absence of ascites.

There are several objections to this concept: the rise of serum albumin did not regularly precede a diuresis although it appeared to accompany the phenomenon; wider experience in a series of 115 cases with ascites revealed 7 cases in which diuresis failed to take place even though the serum albumin rose above 3.5 grams per cent; and, conversely, there were 3 cases in which diuresis took place when values of serum albumin were less than 3.0 grams per cent. Ralli and her associates (3) have cited instances in which diuresis with loss of ascites took place at low values for serum albumin in patients receiving intravenous liver extract. Furthermore, they presented

\footnotetext{
1 The work described in this paper was done under contract recommended by the Committee on Medical Research, between the Office of Scientific Research and Development and Columbia University.
}

evidence suggesting that anti-diuretic substances might play a role in the formation of ascites.

Concentrated human serum albumin solution has provided a means for testing directly the relation of serum albumin and colloid osmotic pressure to ascites formation, for by injecting albumin, the colloid osmotic pressure of the plasma can be raised abruptly. Concentrated serum albumin has been employed by others with the aim of determining its place as a therapeutic agent for cirrhosis of the liver with ascites. Janeway and his associates (4) reported that standard concentrated human albumin solution administered to 6 patients with portal cirrhosis produced no apparent change in ascites formation. The total dosage in 2 instances was 350 and 950 grams. Thorn and his co-workers (5) administered a salt-poor albumin solution to 5 patients with various types of liver cirrhosis associated with ascites and edema. A transient diuresis occurred in all 5 patients after a single infusion of 50 grams and after 3 daily infusions of $\mathbf{5 0}$ grams of albumin. The fluid seemed to have been mobilized from the peripheral edema rather than from the ascites. Two of these patients subsequently lost their ascites after receiving a total dosage of 450 and 500 grams in 27 and 10 days, respectively. Gibson (6) and Kunkel (7) also report that prompt diuresis and loss of ascites occurred in certain patients after the administration of standard concentrated human albumin solution.

The present study was designed to make direct measurement of several factors that might be altered by the injection of concentrated albumin solution. The plan of this experiment was inspired by a similar experiment performed by Luetscher (8) upon patients with nephrosis. Attention was directed at 2 aspects of the problem: (1) measure- 
ment of factors affecting osmotic relations between blood plasma and ascites, and (2) measurement of factors involved in renal function.

The present studies indicate that ascites formation is not determined solely by the level of the plasma colloid osmotic pressure, and they suggest that other factors, such as permeability of the portal vascular bed and alterations in water metabolism, are involved.

\section{PATIENT MATERIAL AND PROCEDURE}

The 3 patients selected for study had been in the hospital for 7, 8, and 21 months preceding the experiment and were stabilized with regard to their disease. That is, they manifested no tendency towards regression or progression of the disease at the time of these observations. All 3 had persistent ascites, hypoalbuminemia, and minimal edema. Patients D. and G. appeared to have classical Laennec's cirrhosis. Biopsies of their livers showed the characteristic picture of this disease. Patient $N$. appeared to have healed yellow atrophy (toxic or post-necrotic cirrhosis) as a sequel to infectious hepatitis. Laparotomy subsequent to these studies revealed a very small cirrhotic liver. However, no biopsy was performed. Summaries of their case histories are appended.

The patients were kept in a separate room and were fed a weighed diet containing approximately Protein 120, Carbohydrate 365, Fat 110 grams during a control period of 4 weeks and throughout the experimental period. The salt content of the diet was estimated to be about 5 grams daily. Fluid intake was not restricted. No medications were given during the experimental period.

Measurements were made of transient effects following a single intravenous injection as well as the cumulative effects of 13 to 16 daily injections of concentrated human serum albumin solution. At the time of the first and the tenth injection, studies of renal function were carried out in addition to various determinations on the blood and ascitic fluid. Fasting blood specimens were obtained each day preceding the infusion of albumin solution. The daily body weight, fluid intake and output were recorded.

The albumin solution was administered by gravity with the standard infusion set used by the Medical Corps of the U. S. Navy. A daily infusion of $200 \mathrm{cc}$. of $25 \mathrm{per}$ cent concentrated albumin solution in $0.3 \mathrm{M} . \mathrm{NaCl}^{2}$ was administered in from 30 to 45 minutes. No untoward reactions occurred. The daily infusions were administered for 13,14, and 16 days, respectively, in the 3 patients.

\section{METHODS}

During the control period and at intervals during and after the infusions of albumin solution measurements were made as follows:

2 The material was prepared at the Harvard Fractionation Laboratories, Dept. of Physical Chemistry, from blood collected by the American Red Cross.
Blood: Cell counts, hematocrit, erythrocyte sedimentation rate (9), plasma protein concentration and partition (10), plasma colloid osmotic pressure (11), plasma volume (12).

Ascitic fluid: Cell counts, protein concentration and partitions, fluid volume (13), colloid osmotic pressure.

Urine: Qualitative analysis, non-protein nitrogen, 24hour albumin excretion, assays of anti-diuretic substance (14).

Renal function: Inulin and p-amino hippuric acid clearance, and chloride excretion. Stable plasma concentrations of inulin and p-amino hippuric acid were maintained by an infusion. Urine was collected through a many-eyed catheter. Urine collection periods were generally of 20 minutes and were terminated by a bladder wash. Inulin was measured by a modification of the Harrison method (15), and p-amino hippuric acid by the Bratton and Marshall reaction (16).

Liver function: Bromsulfalein dye test, cephalin flocculation reaction, serum bilirubin, urine urobilinogen excretion, serum cholesterol, and prothrombin time. The methods employed for testing liver functions have been described in a recent report (17).

Nitrogen content of the food was estimated from standard tables. Nitrogen determinations on blood and urine were done by the micro-Kjeldahl method. Aliquots of 3 daily

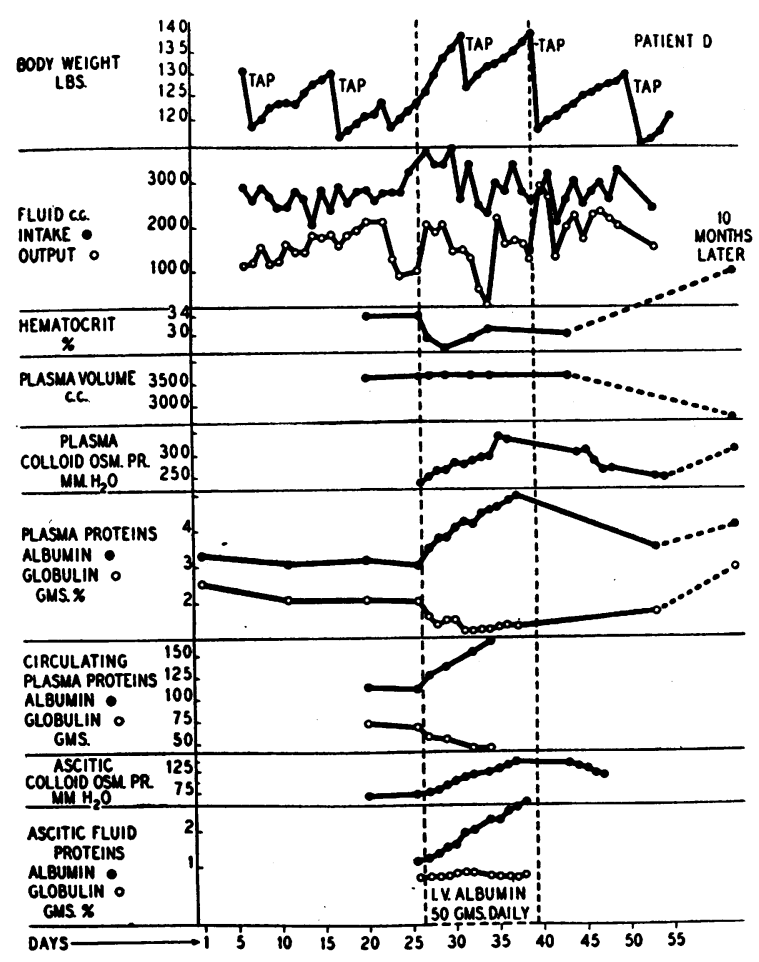

Fig. 1. Effects of Multiple Injections of Concentrated Human Serum Albumin in Patient D

Note the changes observed 10 months later, at a time of spontaneous diuresis and disappearance of ascites. 
urines were pooled and the values for nitrogen averaged. Fecal nitrogen was assumed to be constant.

\section{RESULTS}

After a single injection of concentrated human serum albumin in 3 patients with cirrhosis only moderate changes were observed. A slight rise occurred in the concentration of serum albumin, plasma colloid osmotic pressure, and plasma volume with an associated fall in the hematocrit. The protein constituents and colloid osmotic pressures of the ascitic fluid were unchanged during the first 24 hours after injection.

The effects of multiple injections of concentrated human serum albumin upon these measurements are illustrated by Figures 1,2 and 3 .

Fluid balance. In general the formation of ascites, as shown by weight gain and the frequency of abdominal taps, was not significantly altered. In patient D. (Figure 1) there was slightly increased accumulation of ascites during the experimental period. This pattern may have been com-

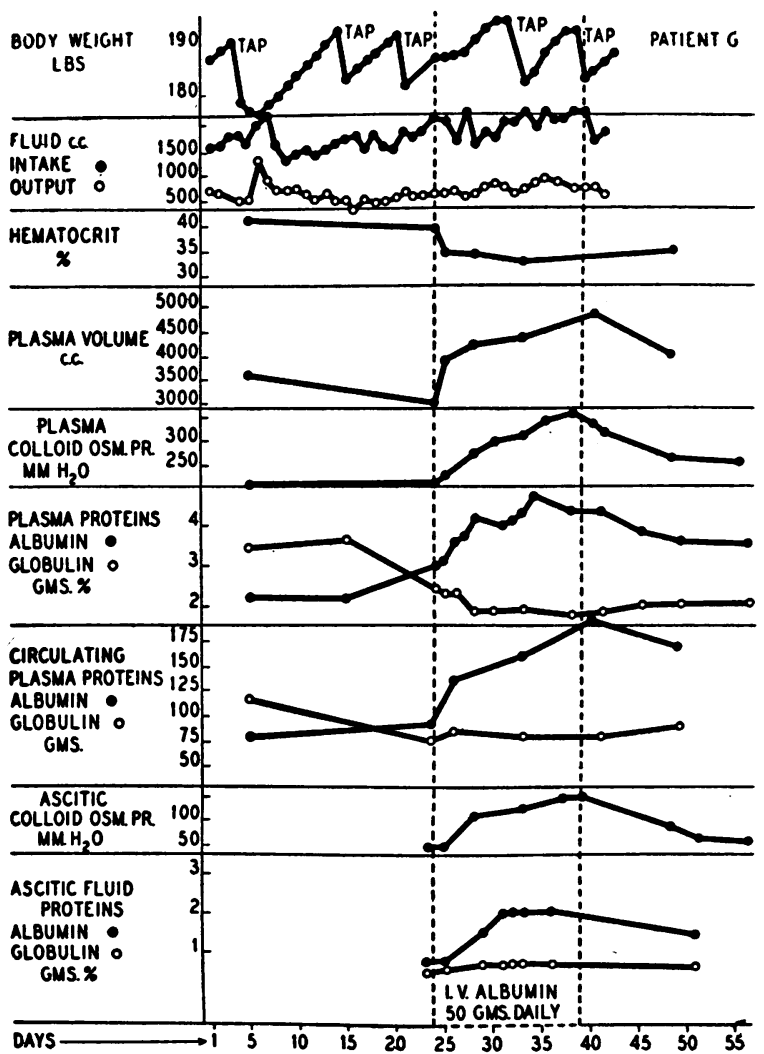

Fig. 2. Effects of Multiple Injections of Concentrated Human Serum Albumin in Patient G

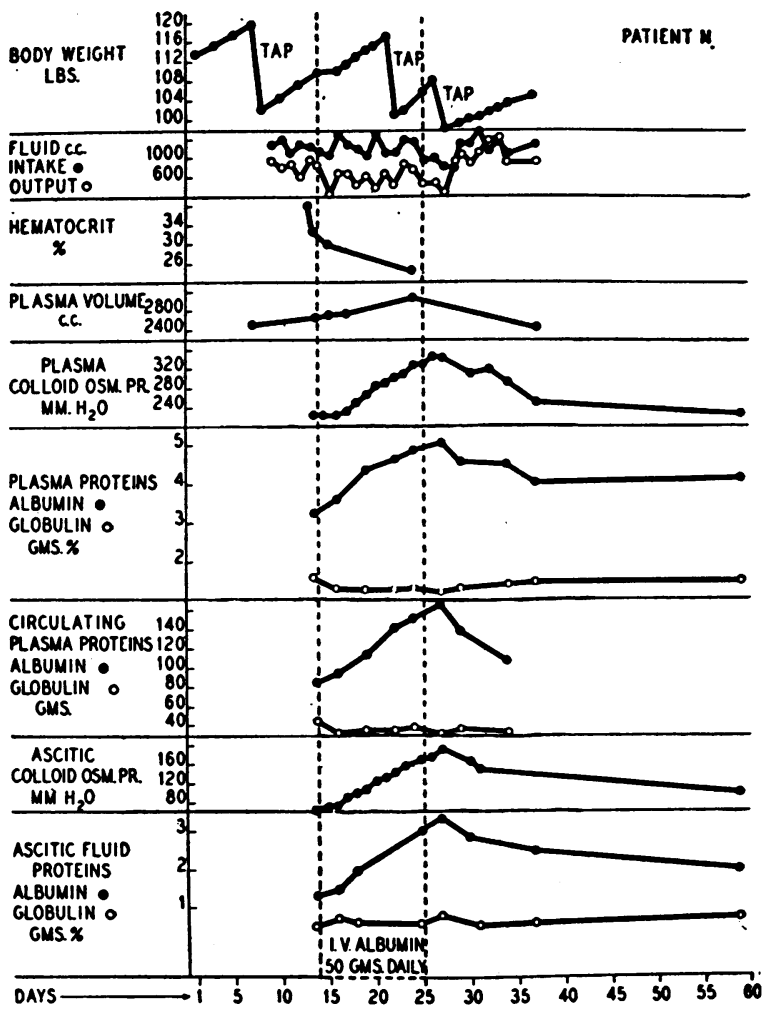

Fig. 3. Effects of Multiple Injections of Concentrated Human Serum Albumin in Patient N

plicated by menstruation which took place towards the end of the experimental period. The relationship of urine output to fluid intake was unchanged by the injections of albumin in the 3 patients.

Plasma volume. The initial high values for plasma volume are in agreement with the findings of Perera (18). After injection of albumin solution there was a measurable increase in plasma volume in 2 instances. The lack of measurable change in patient $\mathrm{D}$. is difficult to explain. The increased values probably are not attributable to loss of dye into the ascites, since there was a lag of 24 hours before it appeared in the ascitic fluid. None appeared in the urine. However, this does not exclude the possibility of the dye being localized in other areas. It is of interest that 10 months after completion of this study the plasma volume had declined from 3600 to $2700 \mathrm{cc}$. in patient D. shortly after there had been a spontaneous diuresis and loss of ascites.

Serum albumin and colloid osmotic pressure. In each case there was a progressive rise in the concentration of serum albumin and in total circu- 
lating albumin (i.e. concentration $\times$ plasma volume) during the administration of concentrated serum albumin, with a return to values only slightly higher than the initial levels in 2 to 3 weeks after cessation of therapy. The plasma colloid osmotic pressure showed a rise and fall parallel to that of the serum albumin. No diuresis took place even though normal values for serum albumin and colloid osmotic pressure were maintained for 10 days in each case. Moreover, in patient D., who failed to lose ascites when the serum albumin value of 4.2 grams per cent (colloid osmotic pressure $340 \mathrm{~mm} . \mathrm{H}_{2} \mathrm{O}$ ) was attained, a "spontaneous" diuresis occurred 9 months later when the serum albumin level was 3.7 grams per cent (colloid osmotic pressure $290 \mathrm{~mm} . \mathrm{H}_{2} \mathrm{O}$ ).

Serum globulin. Decrease in the concentration of serum globulin, observed in all 3 cases, was due apparently to hemodilution (increased plasma volume) since the total circulating globulin was relatively constant. ${ }^{3}$

8 The slight decrease of circulating globulin in patient D. may have been due to error in the estimation of plasma volume in this case.
Ascites. There was a rise both in the concentration of albumin and in the colloid osmotic pressure of ascitic fluid which paralleled the changes occurring in the plasma, but with a lag of about 24 hours. This is shown in Figures 1, 2, and 3. An increase in the ascitic fluid albumin, after the intravenous injection of concentrated albumin solution, was observed in earlier studies by Thorn and his colleagues (5). This finding may explain in part the failure of albumin injections to modify ascites formation in these patients. Because of the increased leakage of protein into the ascitic fluid the gradient between the colloid osmotic pressure of plasma and that of ascitic fluid was only slightly increased. Conditions therefore did not favor the resorption of fluid from the abdominal cavity. A detailed study of factors involved in the transfer of fluid between the plasma and ascitic fluid is presented in a separate report (13).

Renal functions. Values obtained for glomerular filtration rate and plasma flow, measured respectively by the inulin and para-amino hippuric acid clearances, are shown in Table I. After the first injection of concentrated albumin there was a

TABLE I

Renal functions after single and multiple intravenous injections of concentrated albumin solution*

\begin{tabular}{|c|c|c|c|c|c|c|c|c|c|}
\hline Patient & Date & $\begin{array}{c}\text { Experimental } \\
\text { period }\end{array}$ & $\begin{array}{l}\text { Collection } \\
\text { periods } \\
\text { (No.) }\end{array}$ & $\begin{array}{l}\text { Urine } \\
\text { flow }\end{array}$ & $\begin{array}{c}\text { Inulin } \\
\text { clearance }\end{array}$ & $\begin{array}{l}\text { P.A.H. } \\
\text { clearance }\end{array}$ & $\begin{array}{l}\text { Filtrate } \\
\text { fraction }\end{array}$ & $\begin{array}{c}\text { Plasma } \\
\text { chloride }\end{array}$ & $\begin{array}{c}\text { Chloride } \\
\text { excretion }\end{array}$ \\
\hline $\begin{array}{c}\text { D. } \\
\text { Surface } \\
\text { area } 1.48\end{array}$ & $\begin{array}{l}7 / 3 / 45 \\
7 / 12 / 45 \\
4 / 8 / 46\end{array}$ & $\begin{array}{l}\text { Control } \\
1 \text { hr. p. alb. no. } 1 \\
24 \text { hr. p. alb. no. } 9 \\
9 \text { mo. later } \\
\text { (spontaneous } \\
\text { diuresis) }\end{array}$ & $\begin{array}{l}2 \\
2 \\
2 \\
3\end{array}$ & $\begin{array}{l}c c . \text { per } \\
\text { min. } \\
1.16 \\
3.58 \\
1.55 \\
1.55\end{array}$ & $\begin{array}{l}c c . \text { per } \\
\text { min. } \\
122 \\
163 \\
190 \\
134\end{array}$ & $\begin{array}{c}c c . \text { per } \\
\text { min. } \\
512 \\
842 \\
934 \\
1233\end{array}$ & $\begin{array}{c}\text { per cent } \\
23.7 \\
19.4 \\
20.3 \\
10.8\end{array}$ & $\begin{array}{c}\text { m. eq. per } \\
\text { liter }\end{array}$ & $\begin{array}{l}\text { m. eq. per } \\
\min . \times 10^{-2}\end{array}$ \\
\hline $\begin{array}{c}\text { G. } \\
\text { Surface } \\
\text { area } 1.93\end{array}$ & $\begin{array}{l}4 / 26 / 45 \\
5 / 14 / 45 \\
5 / 23 / 45 \\
10 / 18 / 46\end{array}$ & $\begin{array}{l}\quad \text { Control } \\
\text { Control } \\
1 \mathrm{hr} \text {. p. alb. no. } 1 \\
2 \mathrm{hr} \text {. p. alb. no. } 1 \\
24 \mathrm{hr} \text {. p. alb. no. } 9 \\
2 \mathrm{hr} \text {. p. alb. no. } 10 \\
3 \mathrm{hr} \text {. p. alb. no. } 10 \\
5 \mathrm{mo} \text {. later } \\
\text { (ascites present) }\end{array}$ & $\begin{array}{l}2 \\
2 \\
2 \\
1 \\
2 \\
2 \\
1 \\
2\end{array}$ & $\begin{array}{l}0.68 \\
0.43 \\
0.59 \\
0.95 \\
0.49 \\
0.97 \\
0.62 \\
0.84\end{array}$ & $\begin{array}{l}190 \\
194 \\
198 \\
227 \\
213 \\
296 \\
203 \\
216\end{array}$ & $\begin{array}{r}752 \\
821 \\
1250 \\
1900 \\
870 \\
1404 \\
985 \\
658\end{array}$ & $\begin{array}{l}25.2 \\
23.6 \\
15.9 \\
12.0 \\
24 . \\
21 . \\
20.6 \\
32 .\end{array}$ & $\begin{array}{l}108 \\
113 \\
114 \\
112\end{array}$ & $\begin{array}{r}4 \\
14 \\
36 \\
77\end{array}$ \\
\hline $\begin{array}{c}\mathrm{N} . \\
\text { Surface } \\
\text { area } 1.42\end{array}$ & $\begin{array}{l}5 / 14 / 46 \\
5 / 24 / 46\end{array}$ & $\begin{array}{l}\text { Control } \\
1 \text { hr. p. alb. no. } 1 \\
3 \text { hr. p. alb. no. } 1 \\
24 \text { hr. p. alb. no. } 9 \\
1 \text { hr. p. alb. no. } 10 \\
3 \text { hr. p. alb. no. } 10\end{array}$ & $\begin{array}{l}3 \\
2 \\
2 \\
2 \\
2 \\
2\end{array}$ & $\begin{array}{l}2.1 \\
5.95 \\
1.15 \\
0.59 \\
1.87 \\
0.51\end{array}$ & $\begin{array}{r}75 \\
85 \\
112 \\
113 \\
104 \\
120\end{array}$ & $\begin{array}{l}356 \\
503 \\
607 \\
528 \\
592 \\
645\end{array}$ & $\begin{array}{l}21 . \\
16.9 \\
18.4 \\
21 . \\
17.5 \\
18.6\end{array}$ & $\begin{array}{l}111 \\
113 \\
112 \\
109 \\
111 \\
110\end{array}$ & $\begin{array}{l}41 \\
308 \dagger \\
135 \\
25 \\
80 \\
23\end{array}$ \\
\hline
\end{tabular}

* The initial glomerular filtration rates of patients D., G., and N. when corrected to the surface area of $1.73 \mathrm{sq} . \mathrm{m}$. were 142, 172, and 91; the renal plasma flows were 600,709 , and 434 . These values were within the normal range.

$t$ Note increased chloride excretion during spontaneous diuresis in patient $D$. and during transient diuresis after albumin injection in patient $\mathrm{N}$. 
TABLE II

Assay for anti-diuretic substances in urine of a normal subject and patients with cirrhosis

\begin{tabular}{|c|c|c|c|c|c|c|c|c|c|c|}
\hline \multirow{2}{*}{ Date } & \multicolumn{2}{|c|}{$\begin{array}{l}\text { Normal subject } \\
\text { excretion of }\end{array}$} & \multicolumn{2}{|c|}{$\begin{array}{l}\text { Saline control } \\
\text { excretion of }\end{array}$} & \multicolumn{2}{|c|}{$\begin{array}{l}\text { Patient G. } \\
\text { excretion of }\end{array}$} & \multicolumn{2}{|c|}{$\begin{array}{l}\text { Patient } D_{\text {. }} \\
\text { excretion of }\end{array}$} & \multicolumn{2}{|c|}{$\begin{array}{l}\text { Patient } N \text {. } \\
\text { excretion of }\end{array}$} \\
\hline & $\begin{array}{l}25 \text { per } \\
\text { cent }\end{array}$ & $\begin{array}{l}50 \text { per } \\
\text { cent }\end{array}$ & $\begin{array}{l}25 \text { per } \\
\text { cent }\end{array}$ & $\begin{array}{l}50 \text { per } \\
\text { cent }\end{array}$ & $\begin{array}{l}25 \text { per } \\
\text { cent }\end{array}$ & $\begin{array}{l}50 \text { per } \\
\text { cent }\end{array}$ & $\begin{array}{l}25 \text { per } \\
\text { cent }\end{array}$ & $\begin{array}{l}50 \text { per } \\
\text { cent }\end{array}$ & $\begin{array}{l}25 \text { per } \\
\text { cent }\end{array}$ & $\begin{array}{l}50 \text { per } \\
\text { cent }\end{array}$ \\
\hline $4-8-45$ & $\begin{array}{r}\min . \\
78 \\
66\end{array}$ & $\begin{array}{r}\min . \\
100 \\
94\end{array}$ & $\min$. & $\min$. & $\begin{array}{l}\min . \\
114 \\
130\end{array}$ & $\begin{array}{r}\min . \\
174 \\
>180\end{array}$ & $\begin{array}{r}\min . \\
98 \\
108\end{array}$ & $\begin{array}{r}\min . \\
>180 \\
180\end{array}$ & $\min$. & $\min$. \\
\hline $4-21-45$ & & & $\begin{array}{r}76 \\
102\end{array}$ & $\begin{array}{l}140 \\
136\end{array}$ & $\begin{array}{r}88 \\
104\end{array}$ & $\begin{array}{l}130 \\
166\end{array}$ & & & & \\
\hline $5-15-45$ & $\begin{array}{r}122 \\
82\end{array}$ & $\begin{array}{l}152 \\
128\end{array}$ & $\begin{array}{l}62 \\
65\end{array}$ & $\begin{array}{l}92 \\
94\end{array}$ & $\begin{array}{r}>180 \\
114\end{array}$ & $\begin{array}{r}>180 \\
180\end{array}$ & & & & \\
\hline $5-22-45$ & $\begin{array}{r}108 \\
84\end{array}$ & $\begin{array}{l}170 \\
132\end{array}$ & $\begin{array}{l}83 \\
75\end{array}$ & $\begin{array}{l}113 \\
104\end{array}$ & $\begin{array}{r}92 \\
126\end{array}$ & $\begin{array}{l}122 \\
156\end{array}$ & & & & \\
\hline $5-27-45$ & $\begin{array}{l}107 \\
102\end{array}$ & $\begin{array}{l}140 \\
154\end{array}$ & $\begin{array}{l}87 \\
85\end{array}$ & $\begin{array}{l}108 \\
112\end{array}$ & $\begin{array}{l}92 \\
96\end{array}$ & $\begin{array}{l}133 \\
124\end{array}$ & & & & \\
\hline $6-3-45$ & $\begin{array}{l}84 \\
86\end{array}$ & $\begin{array}{l}118 \\
102\end{array}$ & $\begin{array}{l}78 \\
78\end{array}$ & $\begin{array}{l}102 \\
102\end{array}$ & $\begin{array}{l}94 \\
96\end{array}$ & $\begin{array}{l}128 \\
132\end{array}$ & & & & \\
\hline $6-19-45$ & & & $\begin{array}{l}94 \\
92\end{array}$ & $\begin{array}{l}122 \\
120\end{array}$ & $\begin{array}{l}132 \\
132\end{array}$ & $\begin{array}{l}184 \\
178\end{array}$ & & & & \\
\hline $6-26-45$ & & & 94 & 146 & $\begin{array}{l}160 \\
110\end{array}$ & $\begin{array}{r}>180 \\
156\end{array}$ & $\begin{array}{l}146 \\
170\end{array}$ & $\begin{array}{l}180 \\
180\end{array}$ & & . \\
\hline $7-1-45$ & & & 82 & 106 & & & $\begin{array}{l}120 \\
152\end{array}$ & $\begin{array}{l}154 \\
180\end{array}$ & & \\
\hline $7-12-45$ & & & $\begin{array}{l}36 \\
36\end{array}$ & $\begin{array}{l}58 \\
74\end{array}$ & & & $\begin{array}{l}138 \\
136\end{array}$ & $\begin{array}{l}180 \\
162\end{array}$ & & \\
\hline $7-16-45$ & & & same & ntrol & & & $\begin{array}{l}112 \\
122\end{array}$ & $\begin{array}{l}146 \\
150\end{array}$ & & \\
\hline $4-17-46$ & & & $\begin{array}{l}68 \\
90\end{array}$ & $\begin{array}{r}96 \\
116\end{array}$ & & & $\begin{array}{l}86 \\
88\end{array}$ & $\begin{array}{l}110 \\
116\end{array}$ & & \\
\hline $4-23-46$ & & & $\begin{array}{l}76 \\
76\end{array}$ & $\begin{array}{r}96 \\
102\end{array}$ & $\begin{array}{l}72 \\
76\end{array}$ & $\begin{array}{r}102 \\
96\end{array}$ & $\begin{array}{l}80 \\
76\end{array}$ & $\begin{array}{l}104 \\
112\end{array}$ & & \\
\hline $5-12-46$ & $\begin{array}{l}65 \\
75\end{array}$ & $\begin{array}{r}90 \\
100\end{array}$ & & & & & & & $\begin{array}{l}94 \\
92\end{array}$ & $\begin{array}{l}130 \\
120\end{array}$ \\
\hline $5-24-46$ & $\begin{array}{l}76 \\
82\end{array}$ & $\begin{array}{l}100 \\
108\end{array}$ & & & & & & 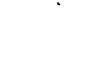 & $\begin{array}{l}146 \\
138\end{array}$ & $\begin{array}{l}>180 \\
>180\end{array}$ \\
\hline $5-26-46$ & same & ntrol & & & & & & & $\begin{array}{l}112 \\
128\end{array}$ & $\begin{array}{l}144 \\
168\end{array}$ \\
\hline $6-24-46$ & $\begin{array}{l}80 \\
80\end{array}$ & $\begin{array}{l}125 \\
128\end{array}$ & & & & & & & $\begin{array}{r}142 \\
>180\end{array}$ & $\begin{array}{r}180 \\
>180\end{array}$ \\
\hline
\end{tabular}

The table shows the time required for rats to excrete 25 and 50 per cent of the hydrating dose after intraperitoneal injection with urinary concentrates. Two groups of 3 male rats were employed for each specimen. Patient G. received 800 grams of concentrated albumin solution between 5-14-45 and 5-29-45. Ascites was present throughout the whole period of observation. Patient D. received 700 grams of concentrated albumin solution between 7-3-45 and 7-16-45. In April 1946 ascites could no longer be detected. Patient N. received 650 grams of concentrated albumin solution between 5-14-46 and 5-26-46. Ascites was present throughout the whole period of observation.

consistent rise in both of these functions. Values for glomerular filtration rate and plasma flow preceding the tenth injection also were higher than the control values preceding albumin therapy, thus indicating a cumulative effect from the preceding 9 injections. Since the filtrate fraction (i.e. ratio of glomerular filtration rate to plasma flow) tended to decrease after the injections of albumin, it ap- 
pears that there was a greater increase of plasma flow than of glomerular filtration.

A transitory diuresis of about 1 hour's duration. was observed in patients $N$. and $D$. after the first injection of concentrated albumin solution. The diuresis was accompanied by an increased rate of chloride excretion in patient $\mathrm{N}$. No measurement of chloride excretion was made in patient $D$. at that time. However, the latter patient showed a sharp increase in this function 9 months later, when she was having a spontaneous diuresis.

Anti-diuretic substance. Urines collected preceding, during, and after the injection of concentrated albumin were assayed for anti-diuretic substances according to the method of Burn as modified by Ham and Landis (14). Each specimen was tested on 2 groups of 3 rats and compared to a control group injected with physiological saline. The values obtained in patients $D$. and $G$. are shown in Table II. Each column represents the time required for hydrated rats to excrete 25 and 50 per cent of water administered by gavage, directly after intraperitoneal injection with the urine concentrate or with saline. Normally 50 per cent of the "hydrating" dose is excreted within 90 to 110 minutes.

Although patients D. and G. both had Laennec's cirrhosis and ascites, the assay of 1 patient's urine showed no marked deviation from normal values whereas the other (D.) showed a constantly delayed response. At the time of a spontaneous diuresis in the latter patient, occurring 9 months after albumin therapy, the urine assay showed normal values. The change from a delayed to a normal response in this patient was consistent with the findings of Ralli and her associates (3). The urine concentrate of patient $N$. (toxic cirrhosis) showed some anti-diuretic activity. The injections of albumin produced no significant alteration in the excretion of anti-diuretic substance in the 3 patients.

In 2 other patients with Laennec's cirrhosis and longstanding ascites, repeated assays of the urine showed varying results, from minimal to marked anti-diuretic activity. In 3 patients with diseases unattended by water retention, delayed responses were at times observed. This variability made interpretation difficult. The presence of hot weather (as pointed out by others) may have exerted an effect in certain instances. For example, the most delayed responses of patient $\mathrm{D}$. took place in June and July.

Because of the lack of homogeneity of the urine concentrate and the technical difficulties involved, the results of this test have been uncertain in our hands.

Nitrogen metabolism. The loss of albumin in the urine was negligible. The average daily urinary excretion of albumin for the week preceding therapy was $0.12,0.19$, and 0.15 grams for the 3 patients. During the 2 -week period of injections the average daily excretion was $0.15,0.37$, and 0.48 grams, respectively.

However, there was considerable loss of albumin into the ascitic fluid. This was estimated by subtracting the total ascitic fluid albumin (volume $X$ concentration) at the beginning of the period from the total ascitic albumin at the end of the period. Preceding albumin therapy the average daily loss of albumin into the ascitic fluid was 9, 8, and 8 grams, respectively, for the 3 patients. During the period of albumin therapy the corresponding average daily losses were 25,32 , and 21 grams. The increased daily loss of albumin into the ascitic fluid during therapy represents 25 to 50 per cent of the albumin injected.

Nitrogen balance was determined in 2 patients. Nitrogen lost as albumin into the ascitic fluid was subtracted from the intake value. Prior to the administration of albumin solution, the daily intake of nitrogen exceeded the output by 2.6 and 5.2 grams. During the period of albumin therapy the daily intake exceeded the output by 7.0 and 9.9 grams, respectively. This increased retention of nitrogen during albumin therapy has been noted by Janeway, Thorn and their associates $(4,5)$. The explanation is not clear. There would appear to be 2 possibilities: either the material was diverted as such to extra-cellular fluid compartments or it was utilized to replace depleted cellular proteins. The fact that these patients were in positive nitrogen balance prior to albumin therapy suggests that there may have been depletion of tissue proteins.

Liver function. Several tests of liver function were performed preceding, during, and after the period of administration of concentrated albumin solution. No significant changes were noted in the bromsulfalein dye test, urine urobilinogen ex- 
cretion, serum cholesterol, cephalin flocculation test, or prothrombin times.

\section{DISCUSSION}

There would appear to be at least 2 aspects to the mechanism of ascites formation in cirrhosis of the liver; namely, (1) factors influencing the localization of fluid within the abdominal cavity and (2) systemic factors favoring the retention of fluid in liver disease in general.

In a previous paper on this subject (1), it was suggested that the formation of ascites was dependent on the combined effect of lowered plasma osmotic pressure and increased portal venous pressure. Even though a fair correlation exists in the large majority of cases between the level of serum albumin and the presence or absence of ascites, this correlation does not necessarily imply a causal relationship. Indeed the present studies reveal that ascites formation is not determined by the level of the plasma colloid osmotic pressure alone and that other factors, such as the permeability of the portal vascular bed, may be important. However, it does not follow that the plasma colloid osmotic pressure has no bearing upon the formation of ascites. Rather, it may be considered as one of several factors, as demonstrated in a separate report (13).

In addition to the localization of fluid within the abdominal cavity, there is a peculiar capacity of the patient with cirrhosis of the liver and with other types of liver disease to retain water (19, 20). This phenomenon could be due to some factor operating within the extra-renal tissues or to an abnormal resorption of salt and water by the kidneys.

Reports by Ralli and her colleagues (3) have suggested that hormonal control of renal function may be the key to the problem, since the urine of patients with liver cirrhosis and ascites contained an anti-diuretic substance when tested in rats. However, it is not implicit that an anti-diuretic substance obtained from the urine is the same substance that is responsible for retention of fluid by the patient. In our experience a correlation between the presence of ascites and the presence of this anti-diuretic substance does not always exist. Further work in this field should help clarify this problem.
The retention of salt and water by these patients is not the result of impaired glomerular filtration, since these values were within normal limits in the 3 patients. The renal tubules apparently were able to reabsorb the greater amount of salt delivered to them by the heightened rate of filtration after the injections of albumin. The transient chloruresis in patient N., occurring when the filtration rate was increased, suggests that it is possible at times to exceed the reabsorptive capacity of the tubules for chloride.

The present studies do not establish the critical factors necessary to initiate sustained diuresis. It is quite possible that more sustained diuresis could have been achieved by the administration of larger amounts of concentrated albumin solution. The refractoriness to therapy of these 3 patients may have been related to the severity and chronicity of the disease process.

\section{SUMMARY AND CONCLUSIONS}

1. Single and multiple intravenous injections of concentrated human serum albumin in 3 patients with cirrhosis of the liver, hypoalbuminemia and longstanding ascites produced neither sustained diuresis nor disappearance of ascites. The clinical status of the patients and tests of liver function showed no apparent changes.

2. After single and multiple injections of the albumin solution the following effects were observed:

(a) increase in circulating plasma albumin without apparent change in circulating globulin;

(b) increase of colloid osmotic pressure of plasma to normal values;

(c) concomitant increase in albumin concentration and colloid osmotic pressure of the ascitic fluid;

(d) increase in plasma volume ;

(e) increase in glomerular filtration rate and in renal plasma flow;

(f) increase in urinary chloride excretion at the time of transient diuresis.

3. The rate of transfer of albumin from plasma into the ascitic fluid increased 3-fold during the period of albumin therapy.

4. The intravenous injection of concentrated human serum albumin produced no significant 
changes in the excretion of anti-diuretic substances.

5. The present studies indicate that ascites formation is not determined solèly by the level of the plasma colloid osmotic pressure. They suggest the participation of other factors, such as changes in the permeability of the portal vascular bed and in salt and water metabolism.

\section{ACKNOWLEDGMENT}

The authors are indebted to Mr. Walter Meyer, Mrs. Greta Heineman, and Mrs. Beatrice Domanski for their technical assistance.

\section{Patient D.}

\section{CASE HISTORIES}

A 36 year old, Irish housewife with a history of alcoholism and grossly inadequate diet entered the Presbyterian Hospital 11/7/44 because of abdominal swelling. Peripheral neuritis had complicated a full term delivery 9 years previously. For, several years there had been anorexia, weight loss, abdominal pain, paresthesias of feet and amenorrhea. For about 1 month fever, abdominal swelling, clay-colored stools, dark urine were observed. After a stay of 1 week at the Presbyterian Hospital she was transferred for study.

Examination disclosed a disoriented, irrational, emaciated woman, with marked icterus and sickly odor.on breath. She exhibited an acneic rash on the face, prominent vascular spiders on face and neck, signs of cheilitis, glossitis, dilated superficial abdominal and thoracic veins, palpable liver and spleen, massive ascites, peripheral edema, and signs of polyneuritis. In addition there was an abscess of the right thigh.

Temperature $100^{\circ} \mathrm{F}$; ; pulse rate 90 per min.; respirations 22 per min.; blood pressure $104 / 72 \mathrm{~mm} . \mathrm{Hg}$; the initial laboratory data were as follows: Rbc 3.0 million pér c. mm.; Hb. 10.8 grams per cent; Wbc 21,000 per c. mm. with 82 per cent polys (stabs 24 ); serum bilirubin $3.4 \mathrm{mgm}$. per cent; blood sugar $91 \mathrm{mgm}$. per cent; nonprotein nitrogen $28 \mathrm{mgm}$. per cent; cephalin flocculation $3+$; bromsulfalein 50 per cent in $30 \mathrm{~min}$; prothrombin 19 sec.; serum cholesterol $118 \mathrm{mgm}$. per cent; serum albumin 2.3 grams per cent; serum globulin 4.6 grams per cent; Wassermann negative. Urine negative except for pyuria.

For 2 weeks the patient was fed by tube with eggnogs (containing yeast) and fruit juices (calories 3000); and she was injected daily with thiamin (100 mgm.), nicotinamide $(300 \mathrm{mgm}$.) and riboflavin $(50 \mathrm{mgm}$.). Because of the fever and persistent leucocytosis she also received sulfadiazine therapy. On 11/30/44 the abscess of her thigh was incised and drained (B. coli). The patient showed marked general improvement, shown by subsidence of fever and jaundice, decreased number of spiders, gain in weight, strength and return of menses. However ascites formation required tapping at 10 to 14 day intervals. Puncture biopsy of the liver on $3 / 1 / 45$ showed histologic changes of Laennec's cirrhosis.
Eight months after entry, trial of intravenous albumin therapy was made. At this time $(7 / 3 / 45)$ the laboratory studies showed Rbc 3.3 million per c. mm., $\mathrm{Hb} .10 .7$ grams per cent, Wbc 6400 c. mm., serum albumin 3.2 gram per cent, serum globulin 2.0 grams per cent, nonprotein nitrogen $22 \mathrm{mgm}$. per cent, serum bilirubin 0.7 mgm. per cent. Flocculation test negative; prothrombin $20 \mathrm{sec}$; urine urobilinogen 1.5 Ehrlich units per hour; serum cholesterol $175 \mathrm{mgm}$. per cent; bromsulfalein 54 per cent in 30 min. Alkaline phosphatase 11.8 Bodansky units; erythrocyte sedimentation rate $38 \mathrm{~mm}$. per hour.

With albumin therapy the serum albumin level rose from 3.2 to a peak of 5.0 grams per cent on 7/14/45 and subsiding after 2 weeks to 3.5 grams per cent. Blood counts and tests of liver function performed at this time and during the next 3 months showed no significant changes from those preceding albumin therapy. Ascites formation continued.

In the ensuing 9 months when the patient received a highly nutritious diet and intravenous liver extract, there was progressive clinical improvement. The liver edge receded; the spleen was no longer palpable; ascites gradually disappeared. She was discharged July 1946, 19 months after entry. At this time laboratory data showed: Rbc 4.1 million per c. mm.; Hb. 15 grams per cent; serum albumin 4.3 grams per cent; serum globulin 2.5 grams per cent; serum bilirubin $0.5 \mathrm{mgm}$. per cent; flocculation test negative; urine urobilinogen $0.56 \mathrm{Ehr}-$ lich units per hour; bromsulfalein test 33 per cent in 30 min.; cholesterol $160 \mathrm{mgm}$. per cent (ester 103). When seen in the Out-Patient Clinic in February 1947, she was ambulatory and well.

\section{Patient N.}

A 37 year old, American-born housewife entered St. Vincent's Hospital in February 1945 because of abdominal swelling. Six years previously, after her last pregnancy she took "reducing pills" and her weight fell from 155 to $103 \mathrm{lbs}$. in 2 months, leaving her in a debilitated state. On advice of her doctor she regained 20 lbs. and then felt much improved. During the past 4 years, while estranged from her husband, her appetite decreased markedly. Although the food intake was meager, her diet was fairly well balanced. There was no story of alcoholism. Her husband and 5 children are living and well.

Her present illness began abruptly in January 1945, with weakness, nausea, vomiting, abdominal pain, jaundice, clay-colored stools, and dark urine in association with a severe upper respiratory infection. Rapid swelling of the abdomen appeared 2 weeks later. The chief findings at St. Vincent's Hospital included jaundice, ascites, and an enlarged tender liver. The patient was given a high protein, high carbohydrate, low fat diet. Because of persistent ascites formation an anastomosis of the right saphenous vein to the peritoneum was performed but without benefit. Ascites accumulated rapidly, requiring paracentesis at intervals of 3 weeks. The patient was transferred to another hospital and thence to the Columbia 
Research Service for further care on $10 / 16 / 45$, which was 10 months after the onset of her illness.

Examination showed a thin, frail, middle aged woman whose abdomen was greatly distended with fluid. Temperature $99^{\circ} \mathrm{F}$; p pulse 80 per min.; blood pressure $120 / 70$ $\mathrm{mm}$. Hg. The skin and hair were of normal texture. The nasopharynx and tongue appeared normal. There was no glandular enlargement, jaundice, or vascular spiders. Prominent veins coursed over the abdomen and lower thorax. The heart and lungs were normal. There was slight sacral edema but none of the extremities. Neurological, rectal, and vaginal examinations showed no significant changes. Neither liver nor spleen was felt after abdominal paracentesis.

Laboratory findings on admission to the hospital were: Rbc 4.75 million per c. mm.; Wbc 5700 per c. mm.; Hb. 13.4 grams per cent; erythrocyte sedimentation rate $24 \mathrm{~mm}$. per hr.; fasting blood sugar $104 \mathrm{mgm}$. per cent; serum cholesterol $250 \mathrm{mgm}$. per cent (ester 189); serum alkaline phosphatase 28 Bodansky units; serum bilirubin $0.4 \mathrm{mgm}$. per cent; serum albumin 3.1 grams per cent; serum globulin 1.7 grams per cent; non-protein nitrogen $25 \mathrm{mgm}$. per cent; cephalin flocculation test $4+$; thymol turbidity test $3+$; prothrombin time $15 \mathrm{sec}$; urine urobilinogen 0.24 Ehrlich units per hour; bromsulfalein dye test 35 per cent in 30 min.; urinalysis showed $1+$ albumin and increased white cells. Urea clearance 97 per cent of normal; phenolsulfonphthalein test 85 per cent in 2 hours and $10 \mathrm{~min}$.

Three months after entry the edges of the liver and spleen were barely felt. After a nutritious diet and intravenous injections of liver extract she gained in strength and well being but showed no evidence of improved liver function. Ascites required tapping (8000 cc.) every 2 or 3 weeks. Seven months after entry observations were made on the use of intravenous serum albumin. Ten days after the conclusion of these studies the laboratory tests were as follows: Rbc 4.6 million per c. $\mathrm{mm}$.; Wbc 4800 per c. mm.; Hb. 11.1 grams per cent; erythrocyte sedimentation rate $25 \mathrm{~mm}$. per hour; cholesterol 230 mgm. per cent (ester 158); serum bilirubin 0.4 mgm. per cent; cephalin flocculation test $4+$; urine urobilinogen 0.3 Ehrlich units per hour; prothrombin time $17 \mathrm{sec}$; bromsulfalein dye test 34 per cent in 30 min.; serum albumin 4.2 grams per cent; serum globulin 1.3 grams per cent; non-protein nitrogen $27 \mathrm{mgm}$. per cent. Urine was negative except for $1+$ albumin and increased white cells. The above data show no significant changes from previous determinations except for increased serum albumin.

The patient was transferred 4 months later to the Surgical Service for a "button operation" in order to relieve ascites formation. However, this procedure has been without effect. At the time of operation the liver was observed to be very small and nodular. No biopsy was obtained.

\section{Patient $G$.}

A 49 year old tailor entered the Research Service August 20,1943, because of abdominal swelling. For 12 years he had been exposed to benzene cleaning fumes. For 5 years he had been drinking excessively of whiskey and beer. His appetite was good and his diet seemed to be adequate in protein foods. For 1 year there had been spells of vomiting in the morning and libido had decreased. After a severe blow on the abdomen, 3 months preceding entry, he noted tarry stools, persisting 3 weeks. Shortly thereafter he was aware of jaundice, abdominal swelling, edema of the ankles, and oliguria. Three weeks before entry he was admitted to the Presbyterian Hospital. After receiving 2 abdominal paracenteses and supportive care the patient was transferred to the Columbia Research Service for further care.

Examination showed an obese, hairy-chested, middle aged man. Weight $200 \mathrm{lbs}$; t temperature $100^{\circ} \mathrm{F}$.; pulse 90 per min.; blood pressure $120 / 80 \mathrm{~mm}$. Hg. Sclerae were icteric. There were numerous vascular spiders over the arms and posterior thorax. Teeth were carious and the tongue was smooth at the lateral margins. The heart and lungs showed no abnormal findings. The abdomen was greatly extended with bulging flanks, and fluid wave. The firm, non-tender liver was felt one hand's breadth below the costal rim but the spleen was not palpable. There were typical "liver palms" and minimal edema of the ankles. Reflexes were normal except for absent ankle jerks. Vibratory sensation was absent in the toes. The left testicle was atrophied. Painful external and internal hemorrhoids were present.

Laboratory findings at entry were as follows: Rbc 3.54 million per c. mm.; Hb. 13.2 grams per cent; Wbc 8900 per c. mm.; differential smear normal. Urinalysis normal except for +1 albumin. Urea clearance 119 per cent of normal; P.S.P. test 85 per cent in 2 hours $10 \mathrm{~min}$.; plasma albumin 2.6 grams per cent; plasma globulin 4.0 grams per cent; non-protein nitrogen $28 \mathrm{mgm}$. per cent; bromsulfalein test 68 per cent in 30 min.; icterus index 25; cephalin flocculation reaction $3+$; prothrombin time $26 \mathrm{sec}$; t total cholesterol $184 \mathrm{mgm}$. per cent; fasting glucose 113 mgm. per cent; BMR +16 and +9 .

During the 21 months preceding albumin therapy, the patient had persistent fever (100 to $101^{\circ} \mathrm{F}$.), tachycardia, and ascites formation requiring abdominal taps at 7 to 14 day intervals. An umbilical hernia appeared 3 months after entry. Although he showed moderate clinical benefit from dietary care and diuretics there was no change in the rate of ascites formation. A biopsy performed in February 1945 showed changes typical of Laennec's cirrhosis. In June 1945, preceding the albumin therapy the findings were: $\mathrm{Rbc} 4.3$ million per c. $\mathrm{mm}$; Hb. 13.6 grams per cent; Wbc 3400 per c. mm.; plasma albumin 3.0 grams per cent; plasma globulin 2.4 grams per cent; non-protein nitrogen $29 \mathrm{mgm}$. per cent; bromsulfalein dye test 40 per cent in $30 \mathrm{~min}$; ; serum bilirubin $0.9 \mathrm{mgm}$. per cent; cephalin flocculation reaction $1+$; prothrombin time $22 \mathrm{sec}$; total cholesterol $140 \mathrm{mgm}$. per cent; urine urobilinogen excretion 1.8 Ehrlich units per hour.

In June 1945, 21 months after entry, the patient received 16 daily injections of concentrated albumin solution (800 grams). No significant change in his clinical status ap- 
peared during or directly after this experimental period. The laboratory data after the period of albumin injections showed no essential changes other than an increase of plasma albumin.

The patient was maintained on the standard therapeutic regimen during the next 10 months during which no significant changes took place. From May 1946 to April 1947 he received, in addition, intravenous liver extract. At the end of this time a slow, steady diuresis took place with the loss of ascites together with laboratory evidence of clinical improvement.

\section{BIBLIOGRAPHY}

1. Post, J., and Patek, A. J., Jr., Serum proteins in cirrhosis of the liver. I. Relation to prognosis and to formation of ascites. II. Nitrogen balance studies on five patients. Arch. Int. Med., 1942, 69, $67,83$.

2. Post, J., and Patek, A. J., Jr., Serum proteins in relation to liver disorders. Bull. N. Y. Acad. Med., 1943, 19, 815.

3. Ralli, E. P., Robson, J. S., Clarke, D., and Hoagland, C. L., Factors influencing ascites in patients with cirrhosis of the liver. J. Clin. Invest., 1945, 24, 316.

4. Janeway, C. A., Gibson, S. T., Woodruff, L. M., Heyl, J. T., Bailey, O. T., and Newhouser, L. R., Chemical, clinical and immunological studies on the products of human plasma fractionation. VII. Concentrated human serum albumin. J. Clin. Invest., 1944, 23, 465.

5. Thorn, G. W., Armstrong, S. H., Jr., and Davenport, V. D., Chemical, clinical and immunological studies on the products of human plasma fractionation. XXXI. The use of salt-poor concentrated human serum albumin solution in the treatment of hepatic cirrhosis. J. Clin. Invest., 1946, 25, 304.

6. Gibson, S. T., Personal communication.

7. Kunkel, H. G., Treatment of cirrhosis with concentrated human albumin solution. Conference on Liver Injury (Josiah Macy, Jr., Foundation), 1946, p. 124.

8. Luetscher, J. A., Jr., 'The effect of a single injection of concentrated human serum albumin on circulat- ing proteins and proteinuria in nephrosis. $\mathrm{J}$. Clin. Invest., 1944, 23, 365.

9. Wintrobe, M. M., and Landsberg, A., Standardized technique for the blood sedimentation test. Am. J. M. Sc., 1935, 189, 102.

10. Howe, P. E., The use of sodium sulfate as the globulin precipitant in the determination of proteins in blood. J. Biol. Chem., 1921, 49, 93.

11. Hepp, O., Ein neues Onkometer zur Bestimmung des Kolloid-osmotischen Druckes mit gesteigerter Messgenauigkeit und vereinfachter Handhabung. Ztschr. f. d. ges. exp. Med., 1936, 99, 709.

12. Gibson, J. G., II, and Evans, W. A., Jr., Clinical studies of the blood volume. 1. Clinical application of a method employing the azo dye "Evans blue" and the spectrophotometer. J. Clin. Invest., 1937, 16, 301.

13. Mankin, H., and Lowell, A., Osmotic factors influencing the formation of ascites in patients with cirrhosis of the liver. J. Clin. Invest., 1948, 27, 145.

14. Ham, G. C., and Landis, E. M., A comparison of pituitrin with the antidiuretic substance found in human urine and placenta. J. Clin. Invest., 1942, 21, 455.

15. Harrison, H. E., A modification of the diphenylamine method for the determination of inulin. Proc. Soc. Exp. Biol. \& Med., 1942, 49, 111.

16. Bratton, A. C., and Marshall, E. K., Jr., A new coupling component for sulfanilamide determinations. J. Biol. Chem., 1939, 128, 537.

17. Colcher, H., Patek, A. J., Jr., and Kendall, F. E., Galactose disappearance from the blood stream. Calculation of a galactose removal constant and its application as a test for liver function. J. Clin. Invest., 1946, 25, 768.

18. Perera, G. A., The plasmic volume in Laennec's cirrhosis of the liver. Ann. Int. Med., 1946, 24, 643.

19. Adlersberg, D., and Fox, C. L., Jr., Changes of the water tolerance test in hepatic disease. Ann. Int. Med., 1943, 19, 642.

20. Labby, D. H., and Hoagland, C. L., Water storage and the movements of body fluids and chlorides during acute liver disease. J. Clin. Invest., 1947, 26, 343 . 